\title{
NOWE MEDIA W EDUKACJI I WYCHOWANIU DZIECI I MŁODZIEŻY Z PERSPEKTYWY WIEDZY I DZIAŁAŃ ICH RODZICÓW
}

\begin{abstract}
Streszczenie: W prezentowanym artykule podjęto rozważania dotyczące roli i znaczenia tzw. nowych technologii w procesie socjalizacji, wychowania oraz edukacji dzieci i młodzieży. Celem tekstu jest zwrócenie uwagi na konieczność podejmowania zaplanowanych i celowych działań profilaktycznych przez środowisko rodzinne, jak również na efektywne zagospodarowanie tzw. nowych technologii, które są już na stałe obecne w naszej rzeczywistości społecznej w procesie edukacji uczniów, ze szczególnym uwzględnieniem dzieci posiadających orzeczenie o stopniu niepełnosprawności. Rodzice wspierając naturalną potrzebę poznawania świata przez swoje dzieci oraz ich ciekawość poznawczą, aby zrozumieć otaczające je zjawiska, potrzebują wsparcia w tym niełatwym dla nich zadaniu. Artykuł prezentuje również wyniki badań przeprowadzonych na grupie rodziców dzieci w wieku 7-12 lat. Badanych podzielono na dwie grupy, rodziców dzieci posiadających orzeczenia o potrzebie kształcenia specjalnego z uwagi na różne dysfunkcje psychiczne oraz nieposiadających takiego orzeczenia. Obie grupy rozmówców różnią się między sobą, jeśli chodzi o zakres dostrzeganych internetowych zagrożeń. Szerszy obraz tego zjawiska wyłaniał się z narracji dorosłych wychowujących dzieci posiadające orzeczenia, co wskazuje na potrzebę wyrównywania szans i dotrzymania kroku pełnosprawnym rówieśnikom, stwarza przy tym jednak liczne trudności w tym niełatwym już i tak procesie wychowawczym dziecka z zaburzeniami w rozwoju.
\end{abstract}

Słowa kluczowe: nowe technologie, proces edukacji i wychowania, wirtualna rzeczywistość, zachowania ryzykowne.

\section{Wprowadzenie}

Prezentowany artykuł porusza aktualny i niezmiernie ważny problem dostępności do nowych technologii oraz korzystania $z$ nich w procesie edukacyjno-wychowawczym dzieci i młodzieży. Opisane badania odnoszą się do dzieci w młodszym 
wieku szkolnym. Przyjmując, że proces wychowania jest celowym i świadomym kompleksem działań kształtujących rozwijającą się osobowość dziecka, a rodzice są najważniejszymi osobami, które tym procesem kierują, oraz to, że podejmowane przez nich działania mają kluczowy wpływ na psychospołeczny rozwój dziecka, przeprowadzono badanie na grupie rodziców dzieci w wieku 7-12 lat. Analizie poddano wiedzę oraz działania podejmowane przez rodziców w związku z wykorzystywaniem przez ich dzieci nowych technologii do różnych celów, jednocześnie zwracając uwagę na potrzebę wspierania współczesnych rodziców w podejmowanym przez nich wysiłku wychowawczym.

\section{Nowe technologie - przegląd badań}

W literaturze pedagogicznej sporo uwagi poświęca się możliwościom zastosowania i wykorzystywania nowych technologii, zarówno do nauki, jak i zabawy. Coraz większy nacisk kładzie się także na uwypuklanie zagrożeń i negatywnych skutków, jakie niosą ze sobą wszechobecne multimedia, zwłaszcza dla dzieci młodszym wieku szkolnym. Zagrożenia te są różnorodne, począwszy od przypadkowych kontaktów z osobami czy tekstami zawierającymi nieodpowiednie dla ich wieku treści, poprzez przemoc w cyberprzestrzeni, kiedy to stają się jej ofiarami, ale i nierzadko sprawcami, aż po patologiczne formy przystosowania się do tej rzeczywistości określane mianem nowych uzależnień, jak np. fonoholizm (Stolińska 2008, s. 179). Niewątpliwie multimedia stanowią jedno z najpoważniejszych wyzwań wychowawczych zarówno dla rodziców, jak i nauczycieli, to oni bowiem reprezentują podstawowe, główne środowiska wychowawcze dla dzieci i młodzieży. W tym kontekście A. Skreczko podkreśla naczelną rolę rodziców w uczeniu dzieci zarówno racjonalnego korzystania z mediów internetowych (wymiar czasu, częstotliwość, rodzaj treści), jak i stosunku do nich, co powinno być refleksyjne i krytyczne. Taka edukacja medialna winna, jego zdaniem, być różnorako uzupełniania, np. przemyślanym zagospodarowywaniem dzieciom czasu wolnego, m.in. poprzez rozwijanie ich zainteresowań. Dodatkowo autor przypomina, że to szkoła i współpracujące z nią poradnie psychologiczno-pedagogiczne, instytucje samorządowe i Kościoły są zobligowane do wspierania rodziców w wypełnianiu ich roli, także w omawianym zakresie. Dzieje się to poprzez organizowanie i realizowanie spotkań indywidualnych oraz prelekcji czy programów profilaktycznych dotyczących mediów zarówno dla dzieci, jak i dla ich rodziców (Skreczko 2008, s. 182-186). Obcowanie najmłodszych dzieci z multimediami stało się sprawą i problemem społecznym. Od 2004 roku w Polsce, za sprawą działalności Fundacji „Dzieci Niczyje”, ruszyły kampanie społeczne, które miały zwrócić uwagę samych użytkowników i ich rodziców na możliwości zagrożeń i ich skutki wyłaniające się za sprawą uczestnictwa w cyberprzestrzeni.

Niezwykle istotnych ustaleń $\mathrm{w}$ obrębie przyjętej przeze mnie problematyki badań dokonano w ramach projektu realizowanego za pomocą wywiadów 
kwestionariuszowych na ogólnopolskiej próbie wśród rodziców i opiekunów dzieci w wieku 7-17 lat, które w domu mają zapewniony dostęp do internetu. Z ustaleń badawczych wynika, że zdecydowana większość, bo aż 96 proc. rodziców ma świadomość, że to na nich spoczywa odpowiedzialność, aby zapewnić dzieciom bezpieczne korzystanie z sieci. Dodatkowo, podobny jest odsetek osób badanych rozmawiających na ten temat $\mathrm{z}$ dziećmi, jednak ok. połowa $\mathrm{z}$ nich nie uwzględnia $\mathrm{w}$ tych rozmowach tematu cyberprzemocy. Blisko połowa rodziców przegląda strony odwiedzane prze ich pociechy, a co czwarty rodzic stosuje oprogramowania filtrujące, aby zwiększyć bezpieczeństwo dzieci w cyberprzestrzeni. Niepokoi jednak ustalenie, z którego wynika, że większość rodziców nie jest informowana o niebezpiecznych sytuacjach doświadczanych przez ich dzieci w internecie (http:// www.fdn.pl/badania/fdn).

J. Pyżalski dokonał przeglądu badań polskich i zagranicznych na temat związków między środowiskiem rodzinnym i szkolnym a wchodzeniem młodych w zachowania ryzykowne $\mathrm{w}$ internecie. Wynika $\mathrm{z}$ niego, iż zachowania problemowe podejmowane online są naturalną konsekwencją takich zachowań, które mają miejsce poza wirtualną rzeczywistością. Stąd autor postuluje wsparcie dla działań profilaktycznych w ogóle (bez podziału na przestrzeń wirtualną i rzeczywistą) podejmowanych w domu rodzinnym dziecka czy w szkole (http://www.fdn.pl/ badania/fdn).

$\mathrm{Na}$ uwagę zasługuje także projekt badawczy, realizowany pod auspicjami Instytutu Kultury Miejskiej w Gdańsku, który dotyczy diagnozy kompetencji sieciowych (głównie komunikacyjnych) dzieci w wieku 9-13 lat, wiedzy i działań ich rodziców w tym zakresie, a także szkoły (analiza programów nauczania). Pomysłodawcy i organizatorzy tego projektu podkreślają jego jedynie rozpoznawczy charakter (w tym niereprezentatywność grup badanych). Jak twierdzą, stanowi on jeden z nielicznych projektów upatrujących w internecie możliwość wspomagania u młodych umiejętności wspierających szeroko rozumiany rozwój osobisty (Siuda, Stunża 2012, s. 5-8). Wywiady przeprowadzone z rodzicami miały na celu głównie wykrycie, jak dbają oni o kompetencje swych dzieci pod kątem ich bezpieczeństwa i prywatności w sieci. Większość respondentów, jak pokazują wyniki, deklaruje takie działania, ale nie mają one przełożenia na praktykę dnia codziennego. Dodatkowo rodzice w dużej mierze opowiadali się za aktywną postawą wobec kontroli poczynań ich dzieci w wirtualnej przestrzeni (chodziło o dobrowolny wgląd w działania dzieci, a nie nakazy, zakazy i limity). Choć badani rozumieli istotę i potrzebę zainstalowania na sprzęcie swoich dzieci oprogramowania blokującego niepożądane treści, większość z nich nie zdecydowała się na takie rozwiązanie. Ponadto, duża liczba badanych zadeklarowała, że zgoda na korzystanie ich dzieci z sieci nie stanowi nagrody jako element postępowania wychowawczego. Podobnie, większość z rodziców twierdzi, że rozmawia z dziećmi o działalności w cyberprzestrzeni (zagrożenia, szanowanie praw autorskich, prywatności, selekcja ściąganych treści), wyniki jednak pokazują, że dzieje się to rzadko (Kulczycki i in. 2012, s. 34-44). 
W kwestii ochrony danych osobowych młodych użytkowników sieci wypowiedział się także Generalny Inspektor Ochrony Danych Osobowych. Z raportu sporządzonego na podstawie badań ankietowych przeprowadzonych wśród dzieci i młodzieży w wieku 11-12 lat i 15-16 lat z losowo wybranych 120 szkół podstawowych i gimnazjów działających na terenie kraju wynika, iż najczęściej udostępnianie dane to imię, nazwisko, niezależnie od usług, serwisów czy aplikacji. Ponadto, w zależności od rodzaju aplikacji czy usługi dzieci podają w sieci swój adres e-mailowy, ale także wiek, datę urodzenia, a nawet wrzucają na strony internetowe swoje zdjęcie czy filmy. Jednocześnie najwyższą skłonność do udostępniania danych zanotowano w przypadku korzystania przez nich z portali społecznościowych, e-maili czy komunikatorów internetowych (http://www.giodo.gov.pl).

Obszernych i niezwykle ciekawych danych do analizy, także porównawczych (Polska a inne kraje Europy), dostarczyły badania autorstwa L. Kirwil. Badania tej autorki, oparte o kwestionariusze wywiadów przygotowanych i tłumaczonych dla losowo wybranych dzieci, jak i ich rodziców, stanowiły wycinek większego projektu o zasięgu europejskim Część pierwszą stanowi analiza dotycząca korzystania przez dzieci i młodzież w przedziale 9-16 lat z internetu, a w szczególności wieku, w którym rozpoczynają oni obcowanie z siecią, miejsc, z których następują połączenia, charakteru i rodzaju aktywności w cyberprzestrzeni oraz zagrożeń, jakie się z tym wiążą, a także odwiedzania przez dzieci i młodzież różnego rodzaju portali społecznościowych i związanego z tym zjawiska eksperymentowania z własną tożsamością. Kolejna część raportu dotyczy rodzicielskich sposobów ochrony dzieci przed zagrożeniami internetowymi. Jeśli chodzi o najmłodszych użytkowników sieci, pierwszy kontakt $\mathrm{z}$ internetem przypada zwykle pomiędzy siódmym a 11 rokiem życia, najczęściej poprzez ich własny komputer, w domu rodzinnym. Autorka wskazuje, iż w Polsce dorośli mają mniejszy wgląd w poczynania swych pociech przy komputerze niż przeciętnie rodzice $w$ innych krajach Europy. Z kolei, badania na temat kompetencji dzieci w sieci wykazały, że 61 proc. spośród badanych potrafi zmienić ustawienia prywatności swego profilu na portalu społecznościowym, a ponad połowa zapewnia o umiejętności oceny wiarygodności dostępnych im danych i o tym, że radzi sobie z blokowaniem pewnych treści (np. reklam). Co ciekawe, jak podpowiadają wnioski z raportu, jedna trzecia badanych dzieci wie, jak zmienić ustawienia filtrów blokujących nieodpowiednie dla nich strony. W badaniach widoczna jest też ogólna prawidłowość, w świetle której umiejętność radzenia sobie w cyberprzestrzeni rośnie wraz z wiekiem badanych dzieci. Wśród zagrożeń $w$ trakcie funkcjonowania w wirtualnej przestrzeni najczęściej spotyka się nawiązanie kontaktu z nieznajomymi (z osobami, których dzieci wcześniej nie poznały osobiście) lub zagrażające treści, najmniej częstym niebezpieczeństwem okazała się cyberagresja (ze strony rówieśników). Autorka dokonała także istotnych ustaleń w kwestii eksperymentowania młodych z własną tożsamością. Dzieci, podając się w sieci za kogoś innego (najwięcej w wieku 15-16 lat), są w przyszłości bardziej narażone na kontakt $\mathrm{z}$ treściami i na doświadczenia 
o podtekście seksualnym. Zatem zdaniem L. Kirwil, niezbędnym jest edukowanie dzieci w przedmiotowym zakresie, zwłaszcza tych, które dopiero rozpoczynają swoją przygodę w cyberprzestrzeni (Kirwil 2011, s. 3-30). W części raportu dotyczącej rodziców autorka wyróżniła następujące techniki ochrony dzieci przed negatywnymi skutkami korzystania z sieci: ochronę aktywną (wspólne działania online), ochronę bierną (m.in. poprzez przebywanie w pobliżu dziecka surfującego w internecie), restrykcje (zasady ograniczające czas i sposób korzystania z sieci), wspólne aktywności w internecie, a także posługiwanie się oprogramowaniem umożliwiającym przeglądanie stron, które odwiedzały ich dzieci oraz blokującym i filtrującym konkretne treści. Niepokój budzi fakt, że w przypadku dzieci, które doświadczyły różnych zagrożeń online - zdjęcia i filmy związane z seksem, spotkanie $\mathrm{z}$ osobą poznaną online $\mathrm{w}$ realnym świecie, ponad połowa ich rodziców nie wiedziała w ogóle o zaistniałych zdarzeniach. Natomiast 63 proc. rodziców w Polsce nie wie, że ich dzieci stały się ofiarami cyberagresji ze strony rówieśników.

Wyniki badań sugerują także, że w przypadku opisanych powyżej negatywnych konsekwencji surfowania najwięcej dzieci sięga po wsparcie (głównie emocjonalne) rodziców i nauczycieli. Ci ostatni okazują się pomocni przy nabywaniu kompetencji internetowych. Ostatnie $\mathrm{z}$ badań autorstwa p. Plichty, o którym chciałabym wspomnieć, również dotyczy wiedzy i działań rodziców w kontekście omawianego problemu. Respondenci stanowili grupę 100 celowo dobranych rodziców posiadających dzieci z lekką niepełnosprawnością intelektualną, uczęszczających do szkół specjalnych z terenu woj. łódzkiego i posiadających w domu dostęp do sieci. Narzędzie badawcze stanowił przygotowany wcześniej kwestionariusz ankiety. Autor, publikując wyniki badania, niejednokrotnie podkreślał, iż ma ono charakter pilotażowy i stanowi jedynie próbę zarysowania nowego obszaru badawczego. Z przeglądu dotychczasowych badań odnoszących się do rodziców osób niepełnosprawnych i ich działań na rzecz bezpieczeństwa dzieci w internecie czy korzystania z nowych technologii, dokonanego przez P. Plichtę, wynika, że jest to obszar rzadko eksplorowany przez badaczy (zwłaszcza polskich), a jeśli już to dotyczy głównie osób $\mathrm{z}$ niepełnosprawnością intelektualną. W konkluzjach autor wspomina, iż 70 proc. rodziców przyznaje, że ich dzieci surfują w wirtualnej przestrzeni do trzech godzin dziennie. Wydaje się, że to sporo czasu, biorąc pod uwagę fakt, iż dzieci respondentów to uczniowie, którzy zwykle obligatoryjnie uczęszczają na niejedne dodatkowe zajęcia rewalidacyjne czy terapeutyczne. $\mathrm{W}$ większości rodzice ci są przekonani o edukacyjnych walorach bycia online, ale i nie posiadają kompletnej i realnie oszacowanej wiedzy na temat doświadczanych przez ich dzieci zagrożeń w internecie. Jeśli chodzi o rodzicielskie działania, należą do nich głównie: ograniczanie czasu korzystania z sieci, wspólne z niej korzystanie oraz instalacja programów blokujących. W przypadku tego badania występuje znaczna grupa respondentów, która nie podejmuje żadnych działań lub nie potrafi się wypowiedzieć w omawianej kwestii. Warto tu jednak nawiązać do jednego z wniosków L. Kirwil. Paradoksalnie, dzieci, na których sprzęcie dorośli 
zainstalowali stosowne oprogramowanie, częściej doświadczały przykrych sytuacji i komunikatów w internecie (Kirwil 2011, s. 36).

P. Plichta (2013) przywołuje tezę o „odwróconej socjalizacji” w obszarze użytkowania nowych mediów. Wyniki w tym konkretnym projekcie pokazują, że więcej rodziców nauczyło się czegoś od swoich dzieci, jeśli chodzi o surfowanie w internecie, a nie odwrotnie - sami nie byli przykładem dla dzieci ani też nie służyli im własną wiedzą i doświadczeniem. I tu autor jednoznacznie stwierdza, że ten wniosek ma jedynie charakter wstępny i wymaga dalszego pogłębienia w kolejnych badaniach (Plichta 2013, s. 125-140).

Przedstawione powyżej skrótowo wyniki badań z zakresu prezentowanej w tym artykule problematyki wskazują na to, że nie jest to temat nowy, lecz stale podejmowany. Zwykle badania przeprowadza się w dużych grupach, wśród dzieci i ich rodziców. Skromny jest przy tym dorobek badawczy dotyczący niepełnosprawnych użytkowników nowych technologii oraz ich rodziców, a przecież są to osoby borykające się z różnymi deficytami o charakterze ruchowym, intelektualnym, emocjonalnym oraz w sferze zachowań. Wydaje się, że osoby te są szczególnie podatne czy wręcz narażone na negatywne skutki korzystania z multimediów.

\section{Cel, przedmiot badań, metoda oraz procedura badawcza}

Przedmiotem prezentowanych badań jest wiedza rodzicielska oraz działania podejmowane na rzecz bezpiecznego (głównie dla zdrowia psychicznego) korzystania przez dzieci z nowych technologii (np. telefonu, tabletu, komputera $\mathrm{z}$ dostępem do internetu). Badanie osadzone jest w strategii jakościowej, ma cel praktyczny i służy poszerzeniu i pogłębianiu wiedzy dotyczącej działań rodziców we wspomnianym zakresie.

Grupę badanych stanowili rodzice dzieci w wieku 7-12 lat, które uczęszczały do jednej ze szkół podstawowych z terenu Trójmiasta. Szkoła ta oferuje nauczanie, zarówno w klasach zwykłych, jak i integracyjnych. Respondentami byli rodzice (matka lub ojciec) dzieci przypisanych do obu rodzajów klas. W przypadku klasy integracyjnej chodziło o dzieci legitymujące się orzeczeniem o niepełnosprawności. Dobór osób do badania był celowy, podyktowany względami poznawczymi - rozszerzaniem wiedzy o przedmiocie badania odnośnie rodziców dzieci w wyżej wymienionej kategorii wiekowej, zwłaszcza tych niepełnosprawnych. Badana próba składa się z dziewięciu respondentów; siedmiu kobiet i dwóch mężczyzn, w wieku od 39 lat do 66 lat (pięciu rodziców/opiekunów dzieci niepełnosprawnych i czterech wychowujących dzieci bez rozpoznanych zaburzeń). Liczba badanych osób uwarunkowana była ich dostępnością oraz wyrażeniem zgody na udział w badaniu.

Czynności badawcze zostały zorganizowane w obrębie schematu studium przypadków, który w literaturze metodologicznej określany jest jako zbiorowe instrumentalne studium przypadków, intencjonalnie dobieranych przez badacza w celu pogłębienia analizowanego zjawiska, problemu czy procesu. Za pomocą badania 
została ukazana wielopłaszczyznowość i jak najszerszy obraz zjawiska wybranego do badania. Chodziło więc o analizę problemu odnoszącego się do ogółu, ale przez pryzmat konkretnych doświadczeń osób badanych (Kubinowski 2010, s. 172).

Wnioski płynące $\mathrm{z}$ tak przeprowadzonego badania odnosiły się jedynie do respondentów biorących w nim udział. Powyższe elementy zaistniały w prezentowanym badaniu. Materiały do analizy uzyskano, przeprowadzając z każdą z badanych osób wywiad, częściowo kierowany, skoncentrowany na problemie (Rubacha 2008, s. 140). Pozwalał on osobie prowadzącej badanie na zadawanie pytań otwartych, a rozmówcy na swobodę wypowiedzi w kwestii, o którą był pytany. Dodatkowo przygotowano wcześniej zestaw pytań, który mógł ulec zmianie co do kolejności zadawania pytań albo użycia odpowiednich i zrozumiałych dla danego respondenta słów i sformułowań. Niewykluczone było również zadawanie przez prowadzącego wywiad pytań uszczegóławiających; wszystko po to, aby zebrać potrzebne i możliwie wyczerpujące dane (Rubacha 2008, s. 141). Zastosowanie tej metody zbierania danych pozwoliło na opisanie doświadczeń i działań osób badanych, możliwie najbliżej ich perspektywy oraz uchwycenie kontekstu ich wypowiedzi. Przeprowadzając wywiady $\mathrm{z}$ respondentami, zadawano im pytania $\mathrm{w}$ oparciu o wcześniej przygotowane dyspozycje. Badanie miało charakter indywidualny, bez presji czasowej.

W prezentowanym badaniu poszukiwano odpowiedzi na główny problem badawczy, którzy brzmiał: Co badani rodzice wiedzą na temat korzystania przez ich dzieci z nowych technologii i jakie działania podejmują, aby było to bezpieczne i konstruktywne?

W związku z tym problemem wyróżniono następujące pytania szczegółowe: 1) Czy rodzice wiedzą, jakie skutki (pozytywne, negatywne) może nieść za sobą szeroki dostęp dzieci do nowych technologii?; 2) Co wiedzą rodzice o czasie, częstotliwości i rodzajach aktywności, jakie podejmują ich dzieci jako użytkownicy nowych technologii?; 3) Czy rodzice dzieci z orzeczeniami o niepełnosprawności posiadają większą wiedzę dotyczącą korzyści, jak i ryzyka płynących z wykorzystania nowych technologii?; 4) Jakie sposoby i strategie stosują rodzice, aby uchronić dzieci przed nieracjonalnym korzystaniem z nowych technologii (w tym z internetu) i następstwem tych czynności?; 5) Jakie sposoby stosują rodzice, aby rozwijać u dzieci twórczą postawę w związku z korzystaniem z nowych technologii? i 6) Skąd czerpią wiedzę i pomysły odnośnie działań wychowawczych mających zwiększać bezpieczne i twórcze korzystanie przez dzieci z nowych technologii?

Między kolejnymi spotkaniami z badanymi dokonywano transkrypcji z odbytych już rozmów. Po zebraniu całości materiału badawczego przystąpiono do jego redukcji za pomocą kodowania. Polegało to na uważnej lekturze kolejnych fragmentów wypowiedzi badanych i odkrywaniu zawartych w nich sensów. Następnym krokiem było nadanie nazw tak wyodrębnionym kodom i stosowne ich pogrupowanie. Tym sposobem nakreślono i uszeregowano główne wątki (kategorie analityczne) wyłaniające się z uzyskanego materiału badawczego. Według G. Gibbs 
,kodowaniu podlegać mogą m.in. określone zachowania czy działania respondentów, ich aktywności, stosowane praktyki oraz strategie, ale również ich stany, sposoby przystosowania się do otoczenia czy wzajemne interakcje (Gibss 2015, s. 92-94).

\section{Prezentacja i dyskusja wyników}

Badani byli rodzice/opiekunowie dzieci uczęszczających do jednej ze szkół podstawowych w województwie pomorskim, która organizuje naukę zarówno dla dzieci w tzw. normie ${ }^{1}$, jak i dla posiadających orzeczenie o niepełnosprawności, i daje konkretne wskazania do pracy terapeutycznej (klasy integracyjne). Dzieci respondentów należą do jednej i drugiej grupy. To, co łączy wszystkich badanych, to fakt, że dostrzegają oni daleko idące korzyści i zagrożenia wynikające z użytkowania przez najmłodszych nowych technologii. W podobny sposób wszyscy podejmują działania na rzecz zapewnienia bądź poprawy bezpieczeństwa swoich dzieci, gdy te korzystają ze sprzętów multimedialnych, a także konsultują się w tej sprawie $\mathrm{z}$ innymi osobami. W toku analizy zgromadzonego materiału badawczego ujawniły się dwa przypadki, kiedy rodzice nie podejmowali żadnych działań, aby ich dzieci mogły przy pomocy komputera czy tabletu rozwijać swoją wiedzę, talenty albo redukować widoczne i odczuwalne deficyty. I tu tego typu postępowanie dotyczyło rodziców z obu grup.

Obie grupy rozmówców (rodzice dzieci z orzeczeniami i bez orzeczenia) różnią się między sobą w zakresie dostrzeganych internetowych zagrożeń. Szerszy obraz tego zjawiska wyłaniał się z narracji dorosłych wychowujących dzieci posiadające orzeczenia. W badanej próbie tylko ci właśnie rodzice kojarzyli nieracjonalne korzystanie z nowych technologii z określonymi skutkami zdrowotnymi. Dodatkowo, w przeważającej większości wspomniani rodzicie i opiekunowie wykorzystują nowe technologie do wspierania i wyrównywania braków w rozwoju swych pociech (specjalne programy, karty pracy), ale także jako narzędzie do karania i nagradzania. Ponadto o internecie, traktowanym jako źródło wiedzy i wsparcia (głównie emocjonalnego) dla rodzicielskich działań w tym obszarze, mówili właśnie ci respondentci.

Obserwowane i dostrzegane przez respondentów pozytywne strony szerokiego dostępu dzieci w okresie szkoły podstawowej do nowych technologii dotyczą zasadniczo dwóch najważniejszych w tym okresie rozwojowym zadań, tj. podjęcia nowej roli społecznej - ucznia - i nabywania niezbędnych do wypełniania tej roli, konkretnych umiejętności oraz zdobycia możliwości intensywnego eksplorowania własnych zdolności czy zainteresowań.

1 Pojęcie normy jest używane przeze mnie jako pewnego rodzaju skrót myślowy, tu jako oznaczenie grupy dzieci, u których powołane do tego instytucje i osoby, jak np. poradnie psychologiczno-pedagogiczne czy zespoły/komisje orzekające o niepełnosprawności, nie zdiagnozowały żadnych zaburzeń czy znaczących odchyleń od wyznaczonego dla danego okresu rozwojowego kanonu umiejętności i poziomu wiedzy, które dziecko winno posiadać. 
Badani rodzice/opiekunowie widzą w nowych technologiach potencjał służący rozwojowi albo kształtowaniu u dzieci umiejętności pomocnych w wypełnianiu wspomnianych zadań. Dostrzegają również, że korzystanie z komputera czy tabletu może usprawniać nabywanie przez ich dzieci umiejętności manualnych („Niewątpliwie są również gry, które wyrabiają zręczność i spostrzegawczość, no myślę, że ja jako dziecko nie miałem takich możliwości”), a także intelektualnych („No, na pewno ćwiczenie pewnych deficytów u dzieci, na przykład refleks, no, tutaj te gry są odpowiednie, ale odpowiednie zapamiętywanie, ćwiczenia skupienia, pamięci, to na pewno dają nam możliwości techniczne").

Ponadto, badani, posiadający dzieci niepełnosprawne, wskazywali na możliwości kompensacji różnych dysfunkcji i deficytów, które posiadają ich dzieci za pośrednictwem nowych technologii („Natomiast nowe technologie, które mu ułatwiają uczenie się, na przykład nauka języka angielskiego, gdzie dla niego ta forma podawcza jest lepsza, tutaj z kolei widzę tę dobrą stronę, tak”; „Pani, on tam bajki ogląda, ogląda tam informacje o księżach, jak pisze mu modlitwy kościelne do nauki, no to on tam szuka tego, jak on ma te problemy z mową, to jest dobre dla niego").

Respondenci są również świadomi, że tak szeroki dostęp do nowych technologii może nieść ze sobą negatywne skutki. Analiza wypowiedzi badanych w obrębie tego tematu wskazuje na to, iż dostrzegają oni zagrożenia, które mogą dotyczyć i nierzadko dotyczą czterech obszarów funkcjonowania dzieci: poziomu poznawczego, behawioralnego, emocjonalnego i somatycznego. Rodzicielskie niepokoje w obrębie poznawczego funkcjonowania dzieci dotyczą głównie kontaktu najmłodszych z treściami nieodpowiednimi do ich wieku, które prezentowane regularnie i w nieodpowiedniej formie, proporcjach czy natężeniu mogą wypaczyć wiedzę dziecka o otaczającym go świecie. Oto przykład wypowiedzi: „Na przykład treści, które pokazują rzeczy, które generalnie są przeznaczone dla dorosłych, tak, czyli jakieś drastyczne sceny, sceny działań wojennych na przykład, sceny erotyczne czy wręcz pornograficzne, one nie powinny być oglądane przez dziecko w wieku szkolnym".

W wypowiedziach osób badanych, co może być jednocześnie zastanawiające i ciekawe, takie instytucje, jak szkoła czy poradnia psychologiczno-pedagogiczna, które w ramach przyjętych na siebie obowiązków oferują różnego rodzaju wsparcie, zwłaszcza rodzinom z niepełnosprawnymi dziećmi, przewijają się w odpowiedziach respondentów w kontekście nowych technologii tylko u dwóch rodziców z obu grup badanych. Są to jednak osoby, które nie mogą (bariery finansowe) lub nie muszą (brak konkretnych deficytów czy zaburzeń u dziecka) liczyć na wiedzę i doświadczenie innych specjalistów prowadzących konsultacje w ramach prywatnej praktyki.

Podczas analizy odpowiedzi respondentów, które dotyczyły tego zagadnienia, wyłoniono kategorię główną, nazwaną „nowe działania”, a chodziło o czynności podejmowane samodzielnie i z własnej inicjatywy przez rodziców. Wspomniany termin bliski jest określeniu „innowacja”. Za Encyklopedia pedagogiczną XXI wieku przyjęto definicję innowacji jako: wprowadzanie nowych idei lub praktyk 
w wychowaniu i nauczaniu (Pilch 2004, s. 704). Ponadto, tego typu działania cechuje inwencja twórcza ich autorów oraz zamiar przyczynienia się w wyniku wcielania ich w życie do szeroko pojętego postępu czy rozwoju. Na gruncie praktyk rodzicielskich działania innowacyjne (twórcze) mogą dotyczyć zmiany, udoskonalenia czy uaktualnienia przekazywanych dzieciom treści, ale także metod i środków (narzędzi), za pomocą których konkretne umiejętności czy wiedza są im dostarczane. Do tego celu rozwiązania innowacyjne stosowane są przez pedagogów oraz wychowawców (w tym także rodziców); mogą być wdrażane poprzez przekształcanie i dostosowywanie dotychczasowych środków i metod wychowawczych do obecnych warunków i możliwości dzieci i młodzieży, względnie wprost mogą być implantowaniem konkretnego pomysłu lub czyjegoś rozwiązania. W pierwszym przypadku mowa jest wówczas o działaniach adaptacyjnych, w drugim zaś o adoptowaniu na własny wychowawczy czy edukacyjny grunt i użytek konkretnych rozwiązań (Pilch 2004, s. 703-705).

Wykorzystanie różnych dostępnych powszechnie programów czy rozwiązań wspomagających proces edukacyjny i wychowawczy w przypadku osób badanych ma wymiar czysto techniczny i organizatorski. Zaopatrują oni swoje dzieci w autorskie programy, które wspomagają naukę poszczególnych umiejętności niezbędnych do dalszej nauki w szkole, względnie służących kompensacji zdiagnozowanych u dziecka deficytów. Rodzice mówili: „Ma też oprogramowania do nauki języka angielskiego, matematyki, bo akurat syn ma umysł ścisły, gdzie lubi matematykę, sięgamy tam na wyższą półkę dla niego, żeby mógł się rozwijać i robić to, co lubi, korzystamy z oprogramowania w przypadku ortografii, bo jest już wprowadzona”. Kolejna wypowiedź: „No mamy taki program «Porusz umysł», dostaję linki i informacje, z czego warto korzystać, no, są gry zręcznościowe, układanie szeregów, kolory, literki, liczby tego typu, dlatego mówię, że to taka forma dydaktyczna i rozwijająca go manualnie".

Drugi rodzaj innowacji, jaki wyłonił się w toku analizy odpowiedzi respondentów, opiera się na osobistym zaangażowaniu (uczestnictwie) dorosłego w tych nowatorskich aktywnościach głównie przez:

- modelowanie odpowiednich i przydatnych (zdaniem rodzica) umiejętności u dziecka („No właśnie, jak na przykład wczoraj była taka sytuacja, że potrzebowaliśmy informacji na temat okularów, w książce to było mało, więc synek, chodź wyguglamy to sobie, pokazuję, no i po prostu pokazuję, w jaki sposób może korzystać z sieci”; „Sprawdzamy razem, no, hasło szkoła specjalna i sprawdzamy, jakie są podręczniki albo wpiszę nazwę tej książki, co nauczycielka mu kupuje, no takie rzeczy, co mu się przydadzą"); - dostarczanie wiedzy o możliwościach nowych technologii („Rozmawiałyśmy, tzn. ja i córka, do czego to służy, kiedy to jest potrzebne i co z takimi rzeczami się robi, że nie tylko do zabawy służą i zdobywania informacji, no tak generalnie mówię jej, do czego to służy, jak to można wykorzystać, na przykład w pracy zawodowej"). 
Trzeci, ostatni typ innowacji, który wyodrębniono, nosi nazwę „innowacje zerowe". Są one rozumiane jako deklaracje rozmówców o świadomym niepodejmowaniu żadnych aktywności w opisywanym obszarze. Sytuacja ta dotyczy dwóch osób badanych. Dodatkową kategorią, którą wyłoniono w trakcie analizy odpowiedzi osób badanych, jest kategoria nazwana „technologie wykorzystania instrumentalne". Takie właśnie nazewnictwo nawiązuje do założeń instrumentalizmu pedagogicznego, według którego wiedzę traktuje się z punktu widzenia korzyści, jakie przynosi w praktyce (Okoń 2007, s. 137). W przypadku badanych rodziców/opiekunów poprzez wiedzę rozumie się świadomość, jak ważne, wciągające i atrakcyjne są dla dzieci nowe technologie. Zatem tak wykorzystywane przez dorosłych narzędzia, tablet czy komputer, stanowią „wdzięczne” urządzenia, pomocne w realizowaniu konkretnego celu:

- zagospodarowania dzieciom czasu, a dla rodzica uzyskania pomocy czy odciążenia w wypełnianiu obowiązków opiekuńczych wobec swych pociech („Jest umowa, że jak ja gdzieś na godzinkę wychodzę, bo mam coś do załatwienia i syn zostaje sam, to się z nim umawiam, że w tym czasie może z komputera korzystać, aż ja wrócę");

- jako efektywne narzędzie do ich karania oraz nagradzania („Wiadomo, że jeśli było super zachowanie w szkole, dostaje max trzy punkty na koniec zajęć od Pani, on nam to mówi, jak go odbieramy ze szkoły, że jest dzisiaj max punktów, no to dobra, w nagrodę dostaje dodatkowy czas grania na komputerze").

Respondenci pytani o czas, jaki ich dzieci poświęcają na korzystanie z nowych technologii w domu rodzinnym, wskazywali na użytkowanie komputera od trzydziestu minut do półtorej godziny. Najczęściej pytani podawali wymiar godzina dziennie, i to zarówno w przypadku dzieci nieorzeczeniowych, jak i tych borykających się z różnymi deficytami czy zaburzeniami. Podobnie nie ma znaczących różnic w odpowiedziach rodziców/opiekunów odnośnie do częstotliwości podejmowania takich aktywności przez ich dzieci. Według większości pytanych ich dzieci mają codzienny kontakt z nowymi technologiami, zaś trzech rodziców (dwóch badanych posiadających dzieci z orzeczeniem o niepełnosprawności i jeden rodzic dziecka bez orzeczenia) jest zdania, że najmłodsi spędzają czas przed tabletem czy komputerem zaledwie dwa do maksymalnie czterech razy w tygodniu. Należy brać pod uwagę, że wiedza wszystkich rodziców biorących udział w moim badaniu o czasie, jaki ich dzieci spędzają przed komputerem czy tabletem, może być niedoszacowana czy niekompletna, a sam czas takich dziecięcych aktywności może być różnie przez samych dorosłych liczony i kwalifikowany. Analiza wypowiedzi w obrębie tego zagadnienia ukazuje bowiem, że czas ten jest przez dorosłych uelastyczniany, to znaczy skracany bądź wydłużany w zależności od wieku dziecka, ale i celu, w jakim najmłodsi użytkują wymieniane sprzęty. Oto przykłady wypowiedzi: „No, a najstarszy syn nie ma żadnych ograniczeń, dlatego że jest na tyle mądry, że widzę, co robi, jak jest z nim, nie ma to znaczenia, ile korzysta, korzysta w mądry sposób, gdy gra, wyłącza się po godzinie, on w ogóle 
szuka raczej informacji”; „[...] to z kolei jest uzależnione od tego, czy pracujemy, by się przygotować do lekcji i odrabiania lekcji, bo wtedy jest tego czasu więcej, chyba że forma relaksu i zabawy dla niego, wtedy ten czas jest mocno ograniczany przez nas”; „Wpisujemy i szukamy tych informacji, jak ja jej pokazałam, to teraz raczej sama tak korzysta, znaczy, ja tego nie wliczam do tego głównego czasu przy sprzęcie, bo ja to nazywam pomoc potrzebna do odrabiania lekcji”.

\section{Podsumowanie}

Dokonując podsumowania zebranych danych, można stwierdzić, że:

- im bardziej zróżnicowane obawy w związku z używaniem przez dzieci nowych technologii prezentują osoby badane, tym szerszy jest wachlarz działań, jakie podejmują, żeby zapewnić dzieciom bezpieczeństwo w sieci;

- ilość dostrzeganych przez badanych pozytywnych aspektów płynących z dostępu ich dzieci do internetu nie przekłada się na ilość działań zapobiegających nadmiernej aktywności dzieci w tym obszarze, tzn. kreatywne poszukiwanie zastosowań do celów edukacyjnych i wychowawczych, wprowadzanie aktywności alternatywnych;

- im większy jest zakres konsultacji podejmowanych przez badanych (np. rodzina, znajomi, fora internetowe itd.), tym bardziej prawdopodobne są niejednolite i niespójne, ale też chętniej podejmowane przez rodziców działania zarówno z zakresu bezpieczeństwa w sieci, jak i obu rodzajów wyszczególnionych w tym artykule ,innowacji rodzicielskich”.

\section{Bibliografia}

Pilch T. (red.). (2003) Encyklopedia pedagogiczna. T. 3. Warszawa: Wydawnictwo Akademickie Żak.

Gibbs G. (2015). Analizowanie danych jakościowych. Warszawa: Wydawnictwo Naukowe PWN.

Kirwil L. (2011). Polskie dzieci w Internecie. Zagrożenia i bezpieczeństwo. Częściowy raport z badań EU Kids Online II przeprowadzonych wśród dzieci w wieku 9-16 lat i ich rodziców. Warszawa: SWPS-EU Kids Online-Pl.

Kubinowski D. (2010). Jakościowe badania pedagogiczne. Filozofia. Metodyka. Ewaluacja, Lublin: Wydawnictwo UMCS.

Kulczycki E., Sieńko M., Siuda P. (2012). Wywiad skategoryzowany. W: Dzieci $w$ Sieci - kompetencje komunikacyjne najmłodszych. Raport z badań. Gdańsk: Instytut Kultury Miejskiej.

Okoń W. (2007). Nowy słownik pedagogiczny. Warszawa: Wydawnictwo Akademickie Żak.

Plichta P. (2013). Rodzice dzieci z niepełnosprawnościa intelektualna wobec korzystania $z$ Internetu - próba zarysowania nowego obszaru badawczego i wstępne 
wyniki badań. W: Plichta P., Pyżalski J. (red.). Wychowanie i kształcenie w erze cyfrowej. Łódź: Regionalne Centrum Polityki Społecznej w Łodzi.

Prezentacja wybranych wyników badań uzyskanych $w$ ramach realizacji projekt „Postrzeganie zagadnień zwiazanych z ochrona danych i prywatnością prze dzieci i młodzież", dostępny na: http://www.giodo.gov.pl/plik/id_p/2733/j/pl (otwarty 04.04.2015).

Pyżalski J., Rodzina i szkoła a przeciwdziałanie zaangażowaniu młodych ludzi w ryzykowne zachowania online, Fundacja Dzieci Niczyje, dostępny na: http://www.fdn.pl/badania-fdn (otwarty 09.04.2015).

Rubacha K. (2008). Metodologia badań nad edukacją. Warszawa: Wydawnictwa Akademickie i Profesjonalne.

Siuda P., Stunża G. D. (2012). Wprowadzenie. W: Dzieci w Sieci - kompetencje komunikacyjne najmłodszych. Raport z badań. Gdańsk: Instytut Kultury Miejskiej. Skreczko A. (2008). Pedagogizacja rodziców w zakresie korzystania z mediów. W: Izdebska J. (red.). Media elektroniczne w życiu dziecka - wyzwaniem dla edukacji medialnej. Białystok: Wydawnictwo Trans Humana.

Stolińska A. (2008). Dziecko w społeczeństwie informacyjnym-zagrożenia i perspektywy w jego rozwoju. W: Muchecka B., Kraszewski K. (red.). Dziecko w świecie współczesnym. Kraków: Oficyna Wydawnicza Impuls.

\section{NEW MEDIA IN THE EDUCATION AND UPBRINGING OF CHILDREN AND TEENAGERS FROM A PERSPECTIVE OF THE KNOWLEDGE AND ACTIONS OF THEIR PARENTS}

Abstract: In the presented article the main point concerns the role and meaning of new technologies which are involved in the socialization, the upbringing and education of children. The intent of this article is to indicate the necessity of planned and intentional preventive actions which are taken by both parents and the whole family environment. New technologies are already present in the process of bringing children and teenagers up. It remains to develop them effectively and to include them into this process, minimizing their adverse effects. The article is also presenting findings of parents taken on the group of children at the age of 7 -12. They have been divided in two groups, of parents of children with psychological disorders and without these disorders. Both groups clearly differ between themselves as regards the scope of noticed Internet threats. Parents still need help and they want to cooperate with some specialist to support their children to be active and save in virtual reality.

Keywords: new technologies, risky behaviors, upbringing and education, children and young people, virtual reality.

Justyna Siemionow - doktor habilitowany nauk społecznych, magister psychologii, adiunkt w Zakładzie Patologii Społecznej i Resocjalizacji, w Instytucie Pedagogiki, na Wydziale 
Nauk Społecznych Uniwersytetu Gdańskiego. Wieloletni praktyk w pracy z młodzieżą niedostosowaną społecznie. Zainteresowania naukowe: zjawisko niedostosowania społecznego dzieci i młodzieży, analiza efektywności procesu resocjalizacji nieletnich, czynniki wyznaczające styl myślenia przestępczego nieletnich, przekonania kluczowe oraz samoocena nieletnich niedostosowanych społecznie i możliwości jej zmiany. Monografie autorskie: Niedostosowanie społeczne: działania zmiana efektywność (Warszawa 2011) i Zmiana przekonań utrudniajacych adaptację społeczna u wychowanków Młodzieżowego Ośrodka Wychowawczego (Warszawa 2016). Adres do korespondencji: Uniwersytet Gdański, Wydział Nauk Społecznych, Instytut Pedagogiki, ul. Bażyńskiego 4, 80-952 Gdańsk. Adres e-mailowy: pedjs@univ.gda.pl. 